\title{
The Utilization of Internet Sites 7 Jour Sur La Planèt as a Learning Media of Listening in French
}

\author{
Hesti Fibriasari $^{1}$ \\ Languages and Arts Faculty \\ Medan State University \\ Medan, Indonesia \\ hesti@unimed.ac.id
}

\author{
Zuhri Ramadhan ${ }^{2}$ \\ Computer Sciences Faculty \\ Pembangunan Panca Budi University \\ Medan, Indonesia \\ ramadhanzoe@gmail.com
}

\begin{abstract}
Utilization of internet sites is needed to improve the ability to listen. The goal is the learner can listen directly to native speakers through the program presented at one of the discussed sites of France. The 7 Jour sur la planèt program features videos, sounds, texts and exercises that learner use to improve listening skills in accordance with the level of French language skills. The method used was an experimental method that aimed to find out two control classes that used 7 Jour sur la planèt sites and classes that did not use 7 Jour sur la planèt. The results showed that classes using 7 Jour sur la planèt had better listening capabilities compared to the other class.
\end{abstract}

Keywords - utilization of internet sites; learning media; listening; French language

\section{INTRODUCTION}

The utilization of ICT-based learning media (Information Communication Technology) is very important in today's globalization era. The growth of internet users in Indonesia in 2016 increased very significantly and successful to make Indonesia be the world's largest internet user. Devices used by the population of Indonesia mostly using mobile devices and the rest using a laptop (https://en.techinasia.com/growth-userinternet-in-indonesia-tahun-2016). This situation is very supportive in the field of education; learners must play an active role in the utilization of information technology today. At the State University of Medan (Unimed) has applied KKNI curriculum based on six tasks that are critical book report, critical journal review, mini research, industrial engineering, project, and routine task (http://sumatra.bisnis.com/read/20161030 / 2/65294 / university-country-terrain-developed-curriculum-based-kkni). From the six tasks it appears that the learner should be independent which means all lectures activities in the form of Student Center Learning (SCL). The SCL shows that teachers are only administrators, facilitators, motivators, in the learning process. Nowadays it is easy to find information quickly with the internet. The Internet makes it easier for learners to learn independently. Foreign language learners, especially French, are in desperate need to hear French spoken directly by foreign speakers. Mastery of French language competence can be done by utilizing learning media using internet site. French language learning has an internet site that learners can easily and easily access. The internet sites include www.tv5monde.com, www.bonjourfrance.com and www.francaisfacile.com. The utilization of learning media by using internet site is very helpful for learners in mastering foreign language. All three sites have a variety of programs and packaged in audiovisual.

The advantages of ICT learning model in the learning process is the flexibility to provide solutions for the problems of place, time and space. The learning process can still take place, wherever the learner is with an internet connection that helps the learner to learn independently without having to be in the classroom. The process helps lecturers to run the college three functions of college teaching, researching and performing devotion. Three functions of college will be able to walk by utilizing advanced technology in the current global era. Hamalik (2004: 34) argues that "learning objectives can be achieved well if supported by various factors, among other media education (media learning) ". Utilization of ICT is one of the efforts to utilize learning media aimed at achieving the teaching and learning process. Alternative utilization of learning media is by utilizing internet. Arsyad, (2007: 23) argues that learning media can also help learners in learning media and it can also help learners in generating comprehension, complementing data in interesting and extraordinary media, facilitating the interpretation of data and condensing information.

For the use of learning media, the author will use the internet site www.tv5monde.org in order to improve the ability of French language learners in terms of listening.

\section{METHODOLOGY}

This research was a classroom action research. Classroom action research was a collaboration between researchers and colleagues. From the beginning, the researchers were directly involved in planning the research, doing the teaching and learning process. The researcher performed monitoring, recording, and collecting data assisted by observer to analyze data ending with reporting of research result. So this research would create collaboration or participation between researcher with observer. 


\section{A. RESEARCH DESIGN}

The design of this research used Kemmis and Mc Taggart model. Each activity cycle consisted of four sub activities, namely planning (plan), action (action), observation (observation), and reflection (reflection). The acting component with observing was made as a whole because both activities must be carried out in one unified time, once the action took place, so the observation must be done.

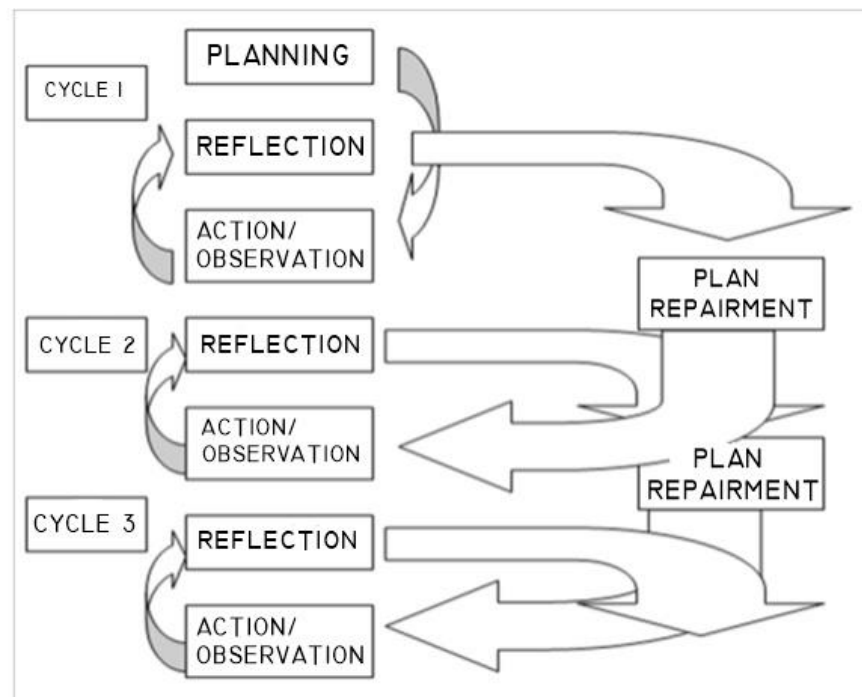

Figure 1. Design Chart of PTK Spiral Model (S, Arikunto, 2008)

The planning stage was the stage of explanation of what, why, when, where, by whom and how the action was performed. The researcher also determined the focus of events that needed special attention to be observed, then the researcher made an observation instrument to help researchers recorded the facts that occurred during the action took place.

The stage of action implementation (acting) was the implementation stage of the contents of the design that was doing the action in class. It should be remembered that in this stage of implementation, implementation must remember and try to obey what has been formulated in the design, but it must be normal and done in any old way.

The observing stage was actually performed during the course of action, in other words the second observation and execution took place at the same time. Observation served to document the influence of related actions. The object of observation was the whole process of related action, its influence, the circumstances, and the constraints and problems that arised in the related context. Observation in this research was data collection activities in the form of process of changing performance of implementation in learning activities.

The reflecting stage was an activity to recount what has been done when the researcher has finished performing the action. If the results of the cycle of the researchers have not obtained the expected results then on reflection researchers also submitted a plan in the next cycle which was an improvement of the previous cycle in accordance with the results of reflection on the previous cycle (S, Arikunto, 2009).

In the reflection stage there were several important activities, namely:

a. Reflect on the strengths and weaknesses of the actions that have been done.

b. Answering about the causes of the situation and conditions that occurred during the execution of the action took place.

c. Estimate a solution to a complaint that appears.

d. Identify the constraints or threats that may be faced.

e. Estimate impacts and implications for planned actions.

The reflection activity consisted of four aspects:

a. Analysis of the observation data;

b. Process of making meaning of data of analysis result

c. Explanation of the analysis;

d. Inference whether the problem was solved by the action that has been done or not.

The reflection activity in this study was related to the number of cycles required. The results of reflection would serve as a guidance in determining whether this research cycle would be added or sufficient. The number of cycles in the classroom action research depended on the outcome of the action. If the outcome of the action indicated an improvement in the quality of the process and the learning outcomes and has reached the desired standard, then the research could be terminated.

\section{B. Time and Location of Research}

The study was conducted in the French Language Education Program State University of Medan in February 2017 to May 2017. Implementation of classroom action research used Kemmis \& McTaggart research model.

\section{Research Objects}

The subjects of this study were students in second semester who were 18 people, consisting of 8 men and 10 women.

\section{Research Data}

The data in this study were collected by researchers through observation. Observation was done by observer by doing observation and recording about how activities of students, lecturer, and media usage of 7 jour sur la planete. Observations were done with prepared observation sheets. In this study aspects of process skills to be measured were observing, using tools and materials, experimenting, asking questions and communicating. 


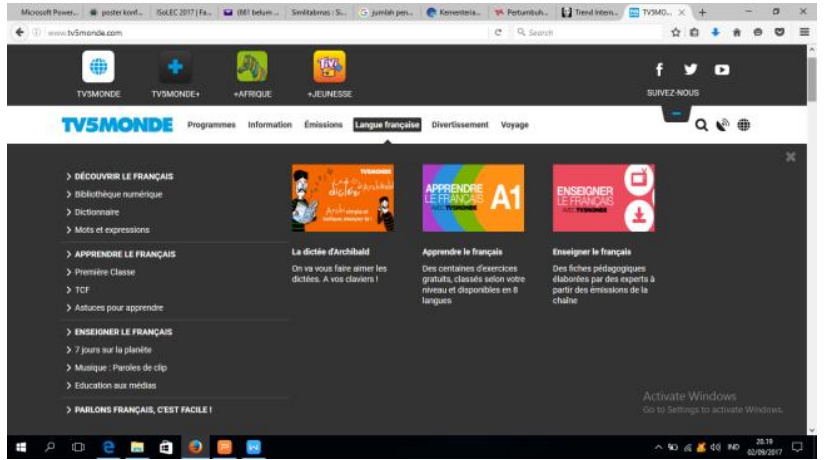

Figure 2

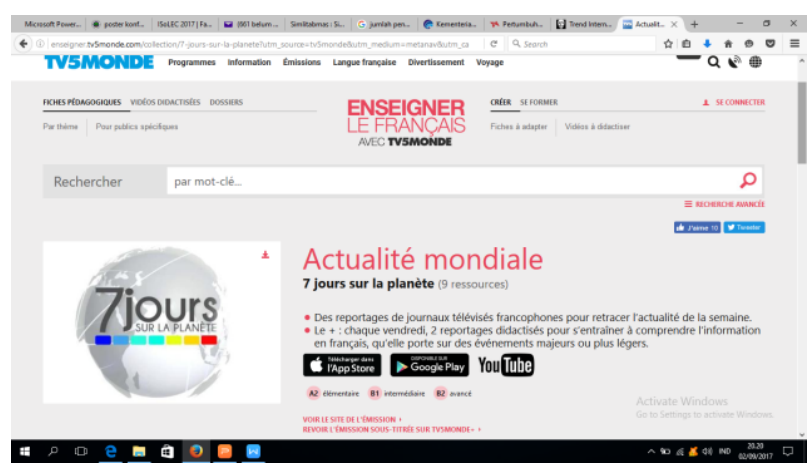

Figure 3

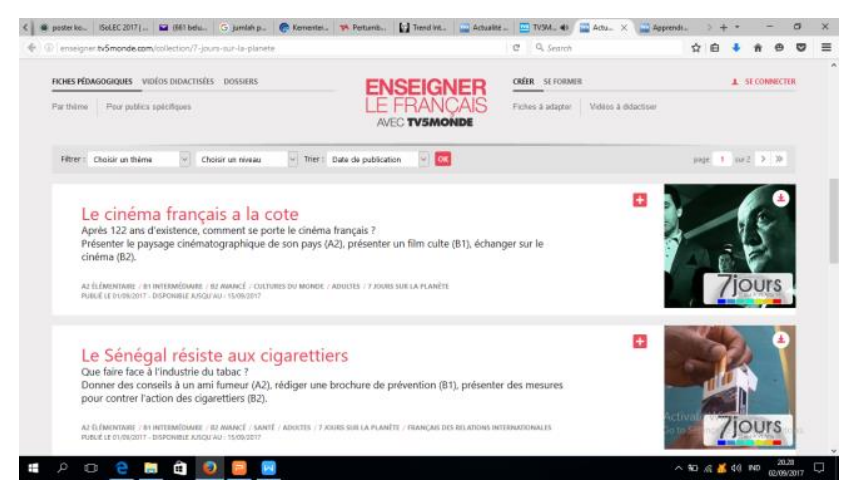

Figure 4

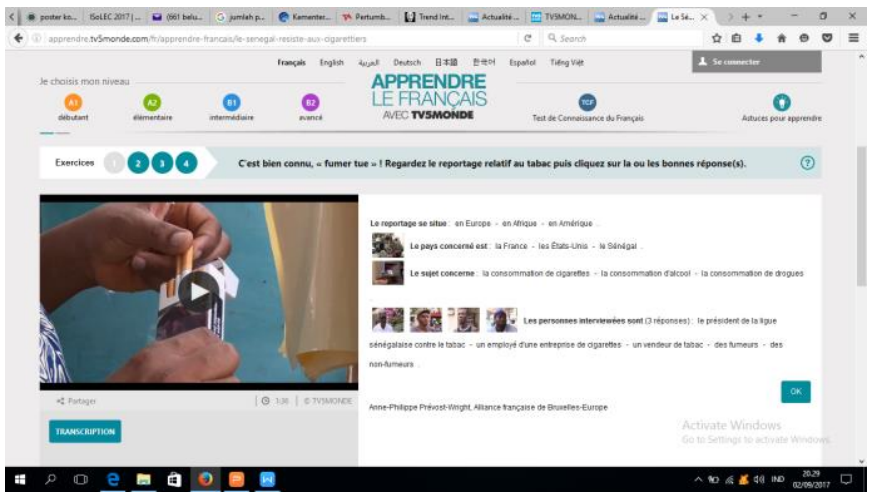

Figure 5

Figures 2.3,4 And 5 are the learning media used in the classroom action research process.

\section{RESULTS AND CONCLUSIONS}

Based on the observation and reflection of the implementation of classroom action research, it can be seen that the utilization of 7 jour sur la planete media can improve the listening skill of second semester students of french language education program unimed. This can be determined from the evaluation of students' work sheet assessment after the implementation of the action. In addition, it is also seen from the increasing of learner activity on each learning conducted by researchers. Implementation of learning with 7 jour sur la planete media which has been implemented in two cycles discuss about le tabac material and its danger. To apply the learning method by using 7 jour sur la planete, the researcher must carry out the learning according to the stages and procedure of media usage of 7 jour sur la planete.

Implementation of learning with 7 jour sur la planete media is appropriate to be implemented by french language education students unimed, because by using the media students are able to hear the conversations from native speakers and are able to know the culture directly through the internet media. implementation of learning process with 7 jour sur la planete media with stages of experimental procedure of expanding from preparing tools such as laptop or handphone android, internet network. the teacher gave explanations to the students about the 7 jour sur la planete media after that the students made conclusions and reports about their experiments. this research was observed by using an observation sheet, so it could be known the ongoing learning with procedure of 7 jour sur la planete media or not .

\section{ACKNOWLEDGMENT}

The research for this paper was financially supported by the Ministry of Research, Technology and Higher Education (RISTEK-DIKTI) and Medan State University, Number 045A / UN33.8 / LL / 2017

\section{REFERENCES}

[1] H.Fibriasari, E. Eviyanti, and F.A. Siregar, "The developement of learning media récéption écrite élémentaire web-based" Advances in Social Science, Education and Humanities Research, vol.128, Indonesia: Malang, 2017, pp. 203-207.

[2] H. Fibriasari, "Prosodic frequency in signaling linguistic distinctions at UNIMED first year non-native french students" International Journal of Humanities and Scocial Science, vol.6 no.10 October, USA: .2016, pp.118-124.

[3] Arsyad, A. 2007. Media Pembelajaran. Jakarta: Raja. Grafindo Persada.

[4] Andi. 2013. Teknik Singkat dan Cepat Menguasai, CSS3. Yogyakarta: Wahana Komputer.

[5] Edyani. 2013. Pengembangan Bahan Ajar Berbasis Web pada Topik Teori Atom Mekanika Kuantum.Bandung: UPI.

[6] Hamalik, O. 2004. Media pendidikan Bandung : Citra Aditya Bakt

[7] Suharsimi Arikunto dkk. 2008. Penelitian Tindakan Kelas. Jakarta: PT Bumi Aksara. 
